\title{
TEACHING WRITING AT THE PRIMARY LEVELS
}

\author{
Irda Sulastri Binte Swandi' \\ Jo-Ann Netto-Shek ${ }^{2}$ \\ Westwood Primary School, Singapore' \\ National Institute of Education, Nanyang Technological University, Singapore ${ }^{2}$ \\ irdasulastri_swandi@moe.edu.sg'; joann.shek@nie.edu.sg
}

First received: 27 December 2016

Final proof received: 30 May 2017

\begin{abstract}
Writing is a critical skill for young learners to master for academic purposes and as a work and life skill. This paper is part of a larger study on the English Language 2010 syllabus and its national curriculum in Singapore particularly in the area of the teaching of writing at the primary levels. In this paper, we report findings from a quantitative content analysis of both the syllabus and the curriculum as "policy texts" (Ball, 2005) to locate alignments and variances in a discussion of their potential impact on classroom instruction. Findings from the analysis of these documents reveal that, on the whole, the national curriculum is aligned not only to current approaches for the teaching of writing but also to the syllabus in terms of instructional principles. However, the findings also reveal a difference in terms of emphasis between both documents that may potentially restrict the realisation of syllabus outcomes in the area of writing instruction at the primary levels.
\end{abstract}

Keywords: teaching writing; teaching English language at the primary levels; syllabus and policy implementation; curriculum implementation

Learning to write in a second language has always been a significant challenge for most learners and in particular young writers (McQuitty, 2014; Tompkins, 2010; Wong \& Hew, 2010). Yet, in a globalised world where the language of trade, economics and education is English, which for some is a second or foreign language, learning to write in English is a significant skill for learning, opportunity and empowerment. The call for solutions to challenges that learners face with learning to write in English Language particularly at the primary levels, has become more urgent than ever before (Cutler \& Graham, 2008; Gilbert \& Graham, 2010). The added pressure from schools and parents as well for English language teachers of young writers to ensure that learners are sufficiently equipped as writers has brought once again to the fore the need for more effective answers for the primary school writing classroom. A review of recent literature produced (Culham, 2003; Spandel, 2005, 2008; Tompkins, 2010), however, reveals that the focus of research in the area of the teaching and learning of writing in English as a second or foreign language at these levels has been on providing instructional insights into teaching methods and approaches. Significantly, there is a dearth of research that provides insights beyond instruction and the classroom for compelling motivators in the realm of policy and national curriculum development that identify the forces that come to bear on the way writing is taught in classrooms at the primary levels, particularly with policies that seek to initiate change in classroom instruction.

This paper attempts to offer such an insight through an analysis of the national curriculum for the teaching of writing in English Language at the primary levels in Singapore. It seeks, through a comparative content analysis of the current English Language syllabus for writing and this national curriculum as "policy texts" (Ball, 2005), to offer another lens of discussing writing instruction for the primary levels.

Teaching Writing: An Evolution of Approaches In a review of the literature for the instructional approaches to teaching writing, there is a distinctive evolutionary development of models and approaches (Pennington, 2013), each almost in response to the inadequacy of existing models to meet the needs of pupils in continually changing educational contexts. To begin, in the 1950s and 1960s, a significant approach to teaching writing that still lingers today in some educational contexts is the product approach (Pincas, 1982; Steele, 1992; Tompkins, 2008). This approach, described as "reductive formalism of traditional composition" (Coe \& Freedman, 1998, p. 41), encapsulated views of writing "as a kind of performance with a specific textual shape and a fixed way of achieving it" (Scott, 1996, p. 141). Following criticisms of this approach (Fowler, 1989), the process (Fowler, 1989; Graves, 1983) and genre approach (B. Derewianka, 1990; Martin, 1984, 1992) attempted to offer new insights into the stages of writing, writing processes and whole-text production strategies as part of "a new and highly productive approach to composition research" (Becker, 2006, p. 25).

Researchers (Emig, 1971; Flower \& Hayes, 1981; Graves, 1983) argued that the product approach had been too preoccupied with the 
production of texts "as a way of telling" (McCrimmon, 1994), a "rhetorical approach to composition" (Pennington, 2013, p. 2) that failed to highlight the importance of the crucial processes involved during writing. Significantly, the product approach that drew "insights of composition theory, cognitive psychology or traditional grammars (Matsuda, 2003)" (Hyland, 2007, p. 149) focussed on reading texts, "absorbing their content, and critiquing them" (Becker, 2006, p. 2). Consequently, the process approach was proposed in the 1980s as an alternative. In the early years of this approach, research such as Murray (1972) affirmed that for pupils to acquire the ability to write well, teachers must initiate pupils into the processes that writers go through because as Nunan (1991) explains "no text can be perfect", certainly not at one go. However, the desire to improve this model of writing was never really sated with calls from researchers such as Sandmel and Graham (2011) who, through a meta-analysis of research on process writing, argued for the explicit teaching of writing processes to develop cognitive structures such as the tapping of pupils' existing schema and content organisation of pupils' understanding. Significant contribution from Flower and Hayes (1981) in terms of a cognitive model that provided "a clearer understanding of the key steps and thought patterns that occur throughout the writing process" sought to replace "traditional linear sequence models" that "describe various steps taken during writing” (Becker, 2006, p. 25).

By 1990s, which Hyland (2007, p. 149) describes as "a period of considerable social and demographic change in education in many countries", further criticisms of the process approach began to surface but more from the area of implementation in classrooms which were now more "culturally, socially, and linguistically diverse places". As Hyland (2007, p. 149) argues that "the old certainties of cognitive homogeneity" no longer supported process models of writing instruction, Pennington (2013, p. 4) adds that "illegitimate textual borrowing and plagiarism, a worldwide problem" ushered in discussions about new approaches to second language writing instruction. Teachers were challenged by the number of stages that each piece of writing required (Horowitz, 1986), and challenged by new instructional processes required of them and of learners (Swales, 1990). To illustrate, research from Raimes (1991, pp. 414-415) discussed that although the process approach was beneficial in terms of the "thinking processes" of the writer, it was less suited to developing learner abilities to write in examination conditions, where time is a constraint and choice limited.

In the 2000s, the genre approach ushered in the "post-process" era (Atkinson, 2003, p. 50) of instructional approaches. Chen (2008, p. 194) states that there are two major approaches to genre that includes "a text-based and a situated-oriented approach (Flowerdew, 2002)". Text-based approaches arose from the New Rhetoric approach (Hyon, 1996) developed from the American tradition of rhetoric and composition whilst a situated model articulated by Halliday (1978) is based on Systemic-Functional Linguistics (SFL). Writing through the lens of genre-based approaches is argued as a "social process" (Halliday, 1978; Miller, 1984) and as Hyland (2007, p. 149) explains "genre refers to abstract, socially recognised ways of using language" used by members of a community, recognising their similarities rather than differences. As such, instructional approaches to writing texts foreground "how texts actually work as communication" (Hyland, 2007, p. 151) with a focus and increased awareness on the roles of readers and writers in terms of audience, purpose, context and culture in the production of texts through "a staged, goal-oriented process" (Martin, 1984). Chen (2008, p. 199) argues that as "utterances draw on past utterances for substances and emanate from the immediate contexts of situation, they are also oriented towards future utterances", genre-based approaches acknowledge a "hidden dialogicality" (Wertsch, 1991) in the writing of texts. And, since the language system is viewed as resources that writers could use in the reading and writing of texts, genre theorists assert that instruction should focus on teaching learners how to "exploit the expressive potential of society's discourse structures instead of merely being manipulated by them" (Hyland, 2007, p. 150). Whilst genre-based approaches have some influence in parts of South-east Asia, Pennington (2013, p. 3) explains that "nowadays, in contexts where the process approach is taught, it is generally combined with some form of textual modelling or genre analysis".

However, challenges to implementation of the genre approach, in particular the SFL-based approach, continue to battle a product-orientation to writing instruction (McQuitty, 2014). Other criticisms also include that given the new age of digital media technology, learning the structure and features of texts as "pure texts" (Bakhtin, 1997, p. 13) is largely inauthentic to a globalised world where texts are a hybrid of several text types (Serafini, 2012). Equally, the charge that "genre instruction inhibits writers' self-expression and straightjackets creativity through conformity and prescriptivism (e.g. (Dixon, 1987)" (Hyland, 2007, p. 152) continues to test the mettle of the approach for classroom purposes.

Recent contributions from Spandel (2005, 2008) direct attention to a compendium of writing skills that writers as learners will need for the production of texts. Culham (2003, p. 20) states that teaching writing skills develop pupils to be "thoughtful assessors" of their own writings and 
equip them with the relevant skills to help them improve their writing. Whilst this body of research gives prominence to explicitly teaching learners writing skills, it seems to serve as a useful body of research that can be situated within process and genre-based instructional models.
Figure 1 provides an overview of the approaches and summary of the arguments to date. To add to Pennington's views that many contexts use a combination of process and genre-based approaches to teach writing, the research indicates that current views are that writing is processorientation, genre-based, cognitive and skills-based.

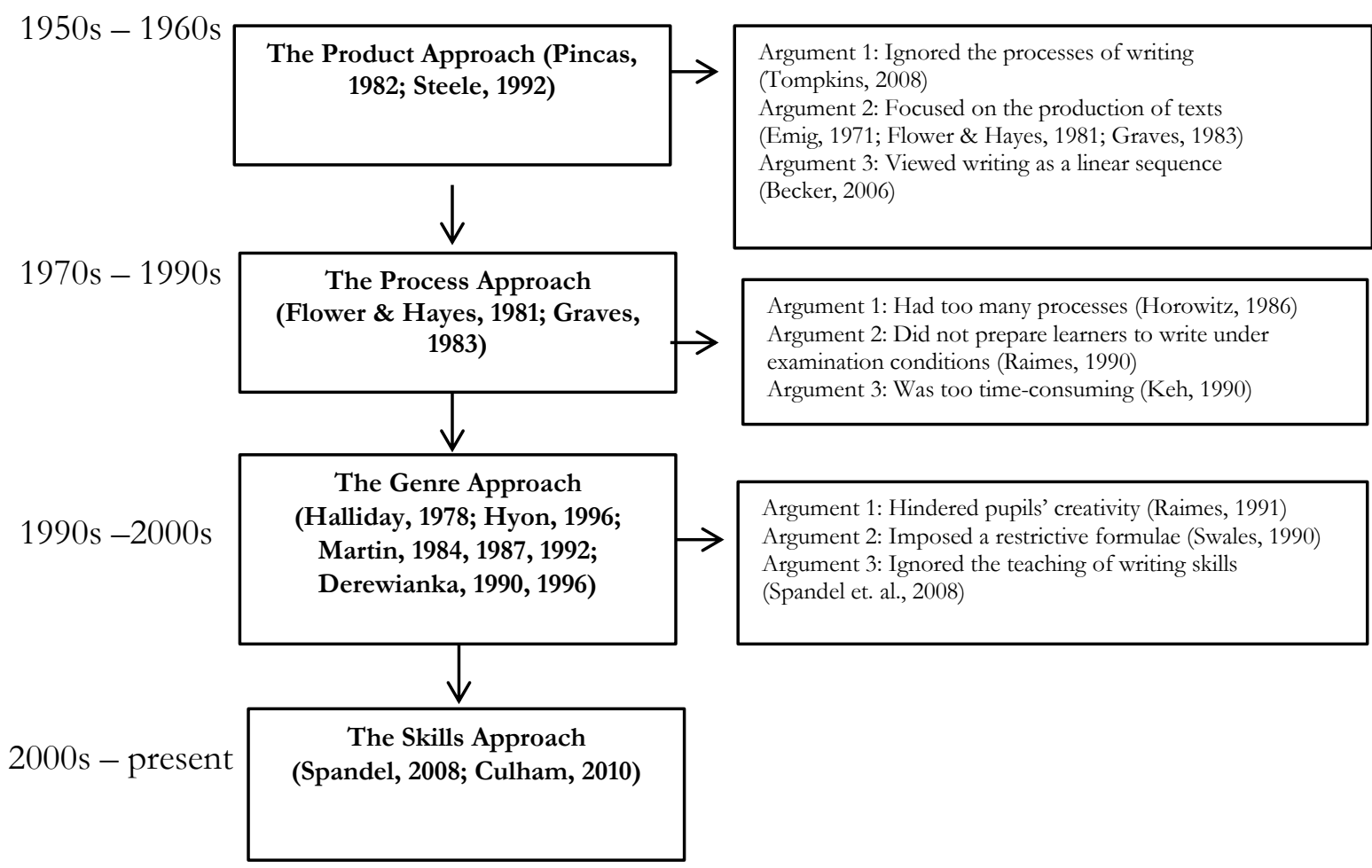

Figure 1. An evolution of writing approaches

\section{The 2010 English Language Syllabus \& The Teaching of Writing}

The 2010 English Language Syllabus is the current syllabus for the teaching of English in Singapore schools and its key mission of "Rich Language, Strong Foundation" attempts to provide the overarching principles of whole-text, literacy-based and process-oriented English language instruction (Richards, 2002). In terms of the teaching of productive skills, that is, speaking, writing and representing at the primary levels, it is asserted in the syllabus that:

"Pupils will speak, write and represent for creative, personal, academic and functional purposes by using language in a sustained manner (e.g., in speech and writing) and by representing their ideas in a range of multimodal texts and text forms. Our most able pupils will do so with increasing ease and inventiveness at higher levels of proficiency." (Ministry of Education, 2010, p. 10)

An analysis of the writing syllabus for the primary levels reveals the following underlying themes:

\section{Language use}

A key feature of the 2010 syllabus is that it "will continue to be a Language Use Syllabus (Emphasis included in the original document) since "effective communication" remains an important aim, if not more important, today. It will continue to emphasise the teaching of internationally acceptable English (Standard English) to our pupils" (Ministry of Education, 2010, p. 7). The teaching of writing is therefore positioned in relationship with reading texts in order "to analyse the effects of language use in texts, once pupils have developed enough selfawareness and have the metalanguage to identify and analyse language choices for creating different types of texts."

At the primary levels, there is a clear progression of language use in terms of knowledge, skills and attitudes.

\section{Text-based}

Another key theme of the 2010 syllabus is the central positioning of texts for teaching and learning. In terms of the teaching of writing at all levels, inclusive of the primary levels as well, is whole text production described as "the sustained 
creation of texts." (Ministry of Education, 2010, p. 59) Texts, defined as both print and non-print texts and for a diverse range of purposes (Ministry of Education, 2010, p. 130), serve to achieve a key principle of the syllabus that language teaching and learning is contextualised in whole texts.

\section{Process-orientation}

Finally, the teaching of writing is positioned as "recurrent" (Ministry of Education, 2010, p. 62) and teachers are urged to engage in instructional processes that reflect its recursive nature. The process of writing is described in terms of three distinct stages of planning, generating and reviewing where learners are positioned as decision-makers "in determining the language and text features of the kind of text to be written, as well as when planning, drafting and revising the texts" (Ministry of Education, 2010, p. 62). In terms of the teaching of writing, though, it is asserted that instruction is located in particular areas of competence as seen in the excerpt provided below:

"Develop writing readiness,
penmanship and spelling accuracy,
and apply skills and strategies for idea
generation, selection, development,
organisation and revision in writing
and representing to address purpose,
audience, context and culture in a
variety of texts." (Ministry of
Education, 2010, p. 60)

The 2010 syllabus reveals that a balance in instruction between knowledge, skills and attitudes is maintained. To illustrate, at the lower primary levels, the focus of writing instruction is largely on ensuring readiness to write, developing psychomotor skills and spelling strategies. Writing instruction for the middle and upper years (ages 912) is directed towards developing a personal cursive hand-writing style as well as writing with "other writing instruments" such as information and communication (ICT) tools.

Overall, writing instruction is described to encompass foundational and complex skills, the use of a wide-range of tools and explicit attention to hand-writing and spelling instruction. In addition, writing instruction is situated as integrated with the learning of other language skills, making space for literacy-based approaches to language learning. Furthermore, there seems to be a specific focus on learner strategies and skills for the teaching of writing, which are categorised in terms of: (a) generating and selecting ideas for writing; (b) developing and organising of ideas in writing and (c) reviewing, revising and the editing of writing. The emphasis on the "application of these skills in the creation of a text is also not linear" and its "recurrent" nature (Ministry of Education, 2010, p. 62) are indicative of a process-orientation to the teaching of writing skills and the production of texts.

\section{The National Curriculum for Primary Schools}

The national curriculum, on the other hand, is a policy-devised derivative (Ball, 2005) developed by policy to assist teachers with the realisation of policy outcomes. Bowe, Ball \& Gold (1992, p. 21) further describe these texts as "second-hand texts" that seek to clarify policy texts. The curriculum comprises units of work developed around good quality children's literature as examples of "rich language" on which instruction and learning is to be contextualised. Each unit of work adopts a literacy approach to language learning, paying attention to both the explicit instruction of knowledge, skills and appropriate attitudes as well as through an integration of language skills. Table 1 provides examples of the composition of a unit of work:

Table 1. The composition of units in national curriculum

\begin{tabular}{lllll}
\hline Unit No. & Text \& Type & Skills Taught & $\begin{array}{l}\text { Curriculum } \\
\text { Included }\end{array}$ & Assessment included \\
\hline Lower primary (6-8 years) & & & \\
\hline Unit 17 & $\begin{array}{l}\text { The Best Pet } \\
\text { (Narrative) }\end{array}$ & $\begin{array}{l}\text { Reading, Listening, } \\
\text { Speaking, Writing }\end{array}$ & $\begin{array}{l}\text { Big Book } \\
\text { Readers } \\
\text { Teachers' Guides }\end{array}$ & Learning Sheets \\
\hline Middle primary (9-10 years) & & & \\
\hline Unit 10 & There's a Monster & Reading, Listening, & Story Sheets \\
& Teachers' Guides & Learning Sheets \\
(Narrative) & Speaking, Writing & Ted & & \\
\hline Upper primary (11-12 years) & & & Learning Sheets \\
\hline Unit 12 & Humpback Turtles & Reading, Listening, & Text / Story Sheets \\
& (Information Report) & Speaking, Writing & Teachers' Guides & \\
\hline
\end{tabular}

\section{Lower Primary (age 7-8 years)}

At the lower primary, the main instructional strategy employed to teach writing is the Language Experience Approach or LEA. This approach developed by Lee, Allen and Lamoreaux (1963) delineates three stages of the procedure, that is,
Class Writing, Group Writing and Individual Writing as shown in Table 2. Key attributes of the approach is that good writing is linked to reading good quality literature, writing comes out of a shared authentic experience from the book or text and that writing is communicative of the shared 
experience (Tompkins, 2008). Stauffer (1970) explains that one of the key strengths of LEA is to tap on pupils' prior knowledge and the authentic experience derived from the book or text to engage them in writing a range of fiction and non-fiction whole texts in response. From the national curriculum, the strategy was modified to incorporate support by introducing new vocabulary and by systematically staging writing from shared to independent writing for each text. For these reasons, the strategy is labelled as the Modified Learning Experience Approach or MLEA.

Table 2: Teaching of writing at the lower primary level

\begin{tabular}{llcl}
\hline & Modified Learning Experience Approach (MLEA) & \\
Level & Text Types & \multicolumn{2}{c}{ Instructional Sequence } \\
\hline Primary One to Two & Narratives & i. & Class Writing \\
& Poems & ii. & Group Writing \\
& Personal Recounts & iii. & Individual Writing \\
& Information Text & & \\
\hline
\end{tabular}

\section{Middle Primary (age 9-10 years)}

At the middle primary, two strategies are advocated in the curriculum to teach writing, that is, MLEA and the Writing Process Cycle or WPC. This mixture is advocated on the basis that the middle years are transitional years from the lower to the upper primary levels. MLEA is suggested for the first semester of the school year while WPC is advocated for the remaining semester with a view to transitioning pupils to writing more complex and academic whole texts. It is explained that at these levels "the objectives of WPC are to focus on writing creatively and to encourage the voice of the pupil as a writer" (Ministry of Education, 2008). Table 3 demonstrates the instructional procedures of both MLEA and the WPC and the text types that are to be learnt.

Table 3: A comparison of writing approaches at the middle primary levels

\begin{tabular}{llcl}
\hline & $\begin{array}{c}\text { Modified Learning Experience Approach (MLEA) } \\
\text { \& Writing Process Cycle (WPC) }\end{array}$ & \\
Level & Text Types & Instructional Sequence \\
\hline Primary Three to Four & Narratives & i. & Class Writing \\
& Poems & ii. & Group Writing \\
& Personal Recounts & iii. & Individual Writing \\
& Information Text & & \\
\hline
\end{tabular}

\section{Upper Primary (age 11-12 years)}

At the upper primary levels, the key strategy advocated for the teaching of writing is the WPC. Although the stages to text production are the same as MLEA, instruction is focussed on writing additional and more complex, non-fiction text types. Pedagogical research on writing instruction (Tompkins, 2010, pp. 306-307) for young writers of this age group explains that it is important that pupils are aware of the unique text features of complex texts and the required technical vocabulary for whole text production. A similar approach is adopted in the national curriculum for the writing of complex non-fiction text types. Table 4 shows the two additional non-fiction text types, that is explanations and expositions, which are taught at these levels.

The analysis of the national curriculum revealed that the main strategies to teaching writing are process-oriented in terms of stages and wholetext genre-based approaches requiring that pupils learn to write a range of complex fiction and nonfiction texts. Strategies advocated in the curriculum have, however, been modified such that the stages and procedures to text production are identical. Additionally, there is little evidence of review strategies that is representative of the recursive nature of writing as conceptualised in the syllabus.

\section{METHOD}

Quantitative content analysis was used to locate if there were potential gaps between the 2010 English Language syllabus and the national curriculum in the area of teaching writing specifically in answer to the following research questions: (1) What approaches, outcomes and goals are advocated for the teaching of writing at the primary levels in the syllabus? And (2) To what extent does the national curriculum achieve the approaches, outcomes or goals as indicated in the syllabus?

As a tool of analysis, quantitative content analysis is described as a tool that researchers use to code and interpret data in order to make valid inferences (Weber, 1990). It is also used to locate and determine the extent of variances between the texts that are examined. In content analysis, data originates from texts, and in this case, policy texts including the text, images and graphics. These texts usually serve the purpose of being seen, read and 
Table 4: Teaching of writing at the upper primary level

\begin{tabular}{llcl}
\hline & \multicolumn{1}{c}{ Writing Process Cycle (WPC) } & & \\
Level & Text Types & Instructional Sequence \\
\hline Primary Five to Six & Narratives & i. & Class Writing \\
& Procedurals & ii. & Group Writing \\
& Personal and Factual Recounts & iii. & Individual Writing \\
& Information Reports & & \\
& Explanations & & \\
& Expositions & & \\
& &
\end{tabular}

used by specific groups of people and in regard to this study, primary school teachers in Singapore. Such texts were analysed for their meanings and interpretations, which ultimately lead to how the text is used by its targeted audience (Krippendorff, 2012).

The analysis began with determining the overall thrust, position and approaches advocated for the teaching of writing in the syllabus document (Ministry of Education, 2010). As there were no ancillary documents for the teaching of writing at the primary levels, this was the only document analysed to locate the purposes of the syllabus for the teaching of writing at the primary levels in particular. Once the approaches, outcomes and goals of the teaching of writing were determined, these served as key themes (Miles \& Huberman, 1994) in terms of "coding and categories" (Rourke \& Anderson, 2004, p.11) for analysis of the national curriculum.

The national curriculum was next analysed in terms of the number of the total units of work for all primary levels. Brophy (2001, p. 24) asserts that units of work or teaching units are "a sequence of ideas or events makes sense and the relationships among ideas are made apparent". Each unit of work was examined to provide an overview of the documents included in the curriculum before the sections specifically written for the teaching of writing were analysed in terms of the themes already identified from the syllabus. Once this was established, sections of each unit specifically focused on the teaching of writing were examined to determine the approaches advocated for the teaching of writing, variations to approaches as suggested in the research literature and whether these segments of the curriculum fulfilled the principles and outcomes of the syllabus. Further, the instructional focus for sections developed for each unit of work was identified (Krippendorff, 2012). Writing tasks were then analysed to determine their alignment to the general approaches to instruction. Findings from this phase of the analysis were then categorised into the following approaches: (a) the product approach (Pincas, 1982; Steele, 1992), (b) the process approach (Flower \& Hayes, 1981; Graves, 1983; Tompkins, 2010), (c) the genre approach (Derewianka, 1990; 1996; Halliday, 1978; Martin, $1984,1987,1992)$ or (d) the skills approach (Culham, 2003; Spandel, 2005, 2008) to determine their alignment with the aims of the syllabus. To illustrate, writing tasks that required pupils to identify the text structure or language features of a "pure text" (Bakhtin, 1997) were classified as "the genre approach". Approaches that were hybrids or combinations of identified approaches from the literature were also coded for both composition and use.

In addition, the frequency of writing approaches was then calculated in answer to the second research question. Instructional time allocated per unit of work was then calculated as an indication of the presence of a predominant approach. For example, at Primary Four (age 10), the curriculum recommended that 12 units of work are advocated for the year, 3 units per term or 1 unit in 3 weeks. Curriculum implementation guidelines (Ministry of Education, 2008) indicate that there are 12 English Language periods per week in schools and for most schools one lesson constitutes minimally 30 minutes. As such, the total time suggested for 1 unit at Primary Four (age 10 years) was found to be 18 hours. The quantitative content analysis of 1 unit taught at Primary Four is provided below in Table 5 as an illustration of analysis for this aspect of the curriculum.

Table 5: Example of the quantitative content analysis of one unit of work for P4

\begin{tabular}{ll}
\hline Characteristics & No. \\
\hline Number of units suggested & 12 \\
\hline Number of terms in one academic year & 4 \\
\hline Number of units to be taught in one term & 3 \\
\hline Number of weeks in one term & 10 (3 units in 10 weeks $)$ \\
\hline Estimated number of weeks to teach one unit & 3 weeks \\
\hline Number of English periods in one week & 12 \\
\hline Number of English periods in three weeks & $3 \times 12=36$ \\
\hline Estimated time allocated to teach one unit & $36 \times 0.5$ hour $=18$ hours \\
\hline Estimated time allocated to teach writing in one unit & 3 hours \\
\hline Percentage of time to teach writing & $17 \%$ \\
\hline
\end{tabular}




\section{FINDINGS}

Findings from a quantitative content analysis summarised as Table 6 reveal that in general, process-oriented and genre-based approaches were advocated for the teaching of writing in both the syllabus and the national curriculum. The strategies introduced in the national curriculum, however, were modified from research-based approaches as advocated in the literature. Modifications to the strategies seemed to be in terms of establishing uniform stages to the production of whole texts. Whilst there was alignment in terms of approaches between the syllabus and the national curriculum, there seems to be a gap in terms of the presence and instruction of writing skills. Writing skills, while foregrounded in the syllabus, are identified as strategies are in the national curriculum. Overall, there was greater alignment in terms of nomenclature between the syllabus and the literature on teaching writing than found in the national curriculum.

The analysis also gave further insights about the curriculum time allocated for the teaching of writing at the primary levels. First, it was found that the number of units of work for each level significantly reduced from 29 units of work at
Primary One (age 6 years) to 12 units of work at Primary 5 (age 11 years). Second, as a whole, the curriculum progresses from fiction texts particularly at the lower primary levels to writing non-fiction texts at the upper primary levels which is consistent with approaches as advocated in the literature (Tompkins, 2008, 2010).

\section{Curriculum Time for Teaching Writing}

A significant finding from the analysis revealed that despite an increase from 6 hours at the lower primary levels (ages 7-8) to 18 hours at the upper primary levels per teaching unit, the total time allocated on the teaching of writing for each level remained at 3 hours across the levels. Further analysis revealed that at the lower primary levels, $50 \%$ of the curriculum is assigned to the teaching of writing. At the middle years (ages 9-10), this percentage reduces to $25 \%$. At the upper primary levels, the percentage of curriculum time is further reduced to $17 \%$ with more time allocated for the teaching of the other language skills. Significantly, as an overview there is a reduction of curriculum time for the teaching of writing more complex text types at the upper primary levels as shown in Table 7.

Table 6: Approaches to the teaching of writing at primary level

\begin{tabular}{|c|c|c|c|c|c|c|c|}
\hline \multirow[t]{2}{*}{ Level } & \multirow{2}{*}{$\begin{array}{l}\text { Number } \\
\text { of Units } \\
\text { Per Level }\end{array}$} & \multirow{2}{*}{$\begin{array}{l}\text { Number of } \\
\text { Fiction } \\
\text { Units }\end{array}$} & \multicolumn{2}{|c|}{$\begin{array}{l}\text { Approaches to Teaching } \\
\text { Fiction Writing }\end{array}$} & \multirow{2}{*}{$\begin{array}{c}\text { Number } \\
\text { of } \\
\text { Non- } \\
\text { Fiction } \\
\text { Units }\end{array}$} & \multicolumn{2}{|c|}{$\begin{array}{l}\text { Approaches to Teaching } \\
\text { Non-Fiction Writing }\end{array}$} \\
\hline & & & $\begin{array}{l}\text { Types of } \\
\text { Approach }\end{array}$ & Presence & & $\begin{array}{c}\text { Types of } \\
\text { Approaches }\end{array}$ & Presence \\
\hline \multirow[t]{2}{*}{ Primary 1} & \multirow[t]{2}{*}{29} & \multirow{2}{*}{$\begin{array}{c}26 \\
(89.6 \%)\end{array}$} & Process & Yes & \multirow{2}{*}{$\begin{array}{c}3 \\
(10.4 \%)\end{array}$} & Process & Yes \\
\hline & & & Genre & Yes & & Genre & Yes \\
\hline \multirow[t]{2}{*}{ Primary 2} & \multirow[t]{2}{*}{25} & \multirow{2}{*}{$\begin{array}{c}21 \\
(84.0 \%)\end{array}$} & Process & Yes & \multirow{2}{*}{$\begin{array}{c}4 \\
(16.0 \%)\end{array}$} & Process & Yes \\
\hline & & & Genre & Yes & & Genre & Yes \\
\hline \multirow[t]{2}{*}{ Primary 3} & \multirow[t]{2}{*}{18} & \multirow{2}{*}{$\begin{array}{c}12 \\
(66.7 \%)\end{array}$} & Process & Yes & \multirow{2}{*}{$\begin{array}{c}6 \\
(33.3 \%)\end{array}$} & Process & Yes \\
\hline & & & Genre & Yes & & Genre & Yes \\
\hline \multirow[t]{2}{*}{ Primary 4} & \multirow[t]{2}{*}{12} & \multirow{2}{*}{$\begin{array}{c}5 \\
(41.7 \%)\end{array}$} & Process & Yes & \multirow{2}{*}{$\begin{array}{c}7 \\
(58.3)\end{array}$} & Process & Yes \\
\hline & & & Genre & Yes & & Genre & Yes \\
\hline \multirow[t]{2}{*}{ Primary 5} & \multirow[t]{2}{*}{12} & \multirow{2}{*}{$\begin{array}{c}4 \\
(33.3 \%)\end{array}$} & Process & Yes & \multirow{2}{*}{$\begin{array}{c}8 \\
(66.7 \%)\end{array}$} & Process & Yes \\
\hline & & & Genre & Yes & & Genre & Yes \\
\hline \multirow[t]{2}{*}{ Primary 6} & \multirow[t]{2}{*}{6} & \multirow{2}{*}{$\begin{array}{c}3 \\
(50.0 \%)\end{array}$} & Process & Yes & \multirow{2}{*}{$\begin{array}{c}3 \\
(50.0 \%)\end{array}$} & Process & Yes \\
\hline & & & Genre & Yes & & Genre & Yes \\
\hline Total: & 102 & $\begin{array}{c}71 \\
69.6 \% \\
(70.0 \%)\end{array}$ & & & \multicolumn{3}{|l|}{$\begin{array}{c}31 \\
30.4 \% \\
(30.0 \%) \\
\end{array}$} \\
\hline
\end{tabular}

\section{Text Type or Genre}

Evidence as presented in Table 6 reveals that the curriculum attended to both the teaching of writing fiction and non-fiction texts at the primary levels. However, across all levels, it was found that $70 \%$ of the units focussed on the teaching of writing fiction texts whilst $30 \%$ attended to the teaching of writing of non-fiction texts. Given the amount of curriculum time carved out for pupils to learn the writing of non-fiction texts as compared to fiction texts, it is likely that pupils on entering secondary schools, where skills for the production of non-fiction and academic texts gain prominence, will need more support. 
Table 7: Percentage of curriculum time allocated for the teaching of writing

\begin{tabular}{lccccc}
\hline \multicolumn{1}{c}{ Level } & $\begin{array}{c}\text { Number of } \\
\text { Units }\end{array}$ & $\begin{array}{c}\text { Number of Units } \\
\text { per Term }\end{array}$ & $\begin{array}{c}\text { Time spend on } \\
\text { writing per unit }\end{array}$ & $\begin{array}{c}\text { Total time per } \\
\text { unit }\end{array}$ & $\begin{array}{c}\text { Percentage of time } \\
\text { to teach writing }\end{array}$ \\
\hline $\begin{array}{l}\text { Primary 1 (ages } \\
\text { 6-7) }\end{array}$ & 29 & 7 & 3 hours & 6 hours & $50 \%$ \\
\hline $\begin{array}{l}\text { Primary 2 } \\
\text { (ages 7-8) }\end{array}$ & 25 & 6 & 3 hours & 6 hours & $50 \%$ \\
\hline $\begin{array}{l}\text { Primary 3 (ages } \\
8-9)\end{array}$ & 18 & 5 & 3 hours & 12 hours & $25 \%$ \\
\hline $\begin{array}{l}\text { Primary 4 (ages } \\
\text { 9-10) }\end{array}$ & 12 & 3 & 3 hours & 18 hours & $17 \%$ \\
\hline $\begin{array}{l}\text { Primary 5 (ages } \\
\text { 10-11) }\end{array}$ & 12 & 3 & 3 hours & 18 hours & $17 \%$ \\
\hline $\begin{array}{l}\text { Primary 6 (ages } \\
\text { 11-12) }\end{array}$ & 6 & 3 & 3 hours & 18 hours & $17 \%$ \\
\hline
\end{tabular}

\section{DISCUSSION}

Bowe, Ball \& Gold (1992, p. 14) explain that "in a very real sense generation and implementation are continuous features of the policy process" revealing of the work of policy texts with regard to the implementation of desired outcomes. Alignment between the syllabus as a primary policy text and the national curriculum as a secondary policy text is crucial for the fulfilment of desired outcomes. In this investigation, the intent of the syllabus and the national curriculum were found to be aligned in terms of the overall approach to teaching writing. Strategies advocated for the teaching of writing at the primary levels such as MLEA and WPC were consistent to the character of process-oriented and genre-based approaches despite modification to instructional procedures as a means of indigenisation.

Modifications to instructional procedures attempted to make explicit the character of such approaches through the instructional sequence, moving from collaborative approaches, that is shared and guided, before individual writing. However, this is also where there seems to be a departure from understandings of process approaches to teaching writing as found in the literature. From a cognitive lens as argued by Flower and Hayes (1981), process approaches pay attention to "key steps and thought patterns that occur throughout the writing process". In the national curriculum, these steps and patterns seem to have been masked by instructional moves in terms of pupil groupings. As thought patterns are implied in the instructional sequences, it is likely that the significant attributes of process orientations to writing instruction may well be missed during enactment.

Furthermore, the attempt to standardise the instructional sequence between key strategies such as MLEA at the lower primary and the WPC at the upper primary encourages a reductionist application of complex writing processes articulated about process writing (Graves, 1983). From the perspective of the national curriculum as the first of its kind since the 1999 Ministry of Education syllabus, prioritizing ease of implementation is understandable but not without some consequence to implementation. Such attempts is likely to offer short term gains since teachers as implementers of the curriculum will have limited understanding of process writing and its encompassed skills that will need to be developed in future syllabus and curriculum documents or through professional development. For the implementation of this curriculum, training workshops were included as part of the process as a derivative implementation text. If this aspect was attended to in the training workshops, it still remains unlikely that a similar reductionist approach was not adopted.

Significantly, as well, the genre approach to writing instruction is emphasised in the curriculum. The findings reveal that there is more attention to fiction genres than there is to non-fiction genres. Instructional representations of the genre approach seems to have focused on providing opportunities for pupils to both read and write a wide range of fiction genres. As standardisation of instructional sequences seems to have been prioritised, little attention has been placed on offering instructional opportunities to manipulate key elements of the genre approach which are audience, purpose, context and culture in order for pupils to achieve mastery over these genres. In this regard, while the curriculum has embraced the genre approach (Derewianka, 1996; Martin, 1984) to teaching writing, its representation in national curriculum may curtail mastery of the critical attributes of writing effectiveness in pupils.

Finally, the findings reveal that while writing skills (Culham, 2003) are foregrounded in the syllabus, it is clear that strategies are foregrounded in the national curriculum. Given the prescriptive nature of the curriculum, potentially this too may have some consequence in terms of equipping learners with the necessary skills for the production of both fiction and non-fiction texts. The themes of 
language use, process-orientation and text-based reveal that the curriculum is aligned to the syllabus in broad ways requiring some adjustment to the strategies suggested to incorporate explicit attention to writing skills. Arguably, without attention to the explicit teaching of writing skills, it is unlikely that pupils' writing will grow to be "more sophisticated in terms of the different and higher-order skills for idea generation, selection, development, organisation and revision, language use and context awareness" (Ministry of Education, 2010, p. 63). Instead, it is likely that the consistent use of processbased strategies alone without attention to the explicit development of writing skills may leave learners to identify and develop writing skills on their own.

Bowe, Ball \& Gold (1992, p. 21) state that "policies...are textual interventions but they also carry with them material constraints and possibilities". The findings from this study of policy texts from the context of text production in the area of writing instruction at the primary levels in Singapore reveal that policy texts with differing emphases are in contestation and are likely to inhibit the achievement of desired outcomes even if supported with training workshops as an additional policy text. The expectation of teachers as implementers to derive a composite understanding of instructional approaches across policy texts within the context of text production is almost certain to lead to limited achievement of student outcomes in schools.

\section{CONCLUSION}

Reading and writing continue to remain the staple skills that learners need to master to be successful in school, work and life. The content analysis of the syllabus and the national curriculum as derivative policy texts reveals that while the main approaches to teaching writing at primary levels in Singapore are process in orientation and genre-based, there is an overwhelming amount of curriculum time carved out for the writing of fiction texts in comparison to non-fiction texts. In addition, the variance in terms of foregrounding or emphasis in both documents may direct teachers as users of the curriculum towards learning newly prescribed instructional strategies rather than achieving syllabus outcomes in a more explicit manner.

\section{REFERENCES}

Atkinson, D. (2003). L2 writing in the post-process era. Journal of Second Language Writing, 12(1), 3-15.

Bakhtin, M. (1997). The problem of the text (An essay in philosophical analysis). Soviet Studies in Literature, 14(1), 3-33.
Ball, S. J. (2005). Education policy and social class: The selected works of Stephen J. Ball. What is policy? Texts, trajectories and toolboxes: Routledge.

Becker, A. (2006). A review of writing model research-based on cognitive processes. In A. Horning \& A. Becker (Eds.), Revision: history, theory, and practice. West Lafayette, Indiana: Parlor Press and the WAC Clearinghouse.

Bowe, R., Ball, S. J., \& Gold, A. (1992). Reforming education and changing schools: Case studies in policy sociology. London \& New York: Routledge.

Brophy, J. (2001). Generic aspects of effective teaching. In M. C. Wang \& H. J. Walburg (Eds.), Tomorrow's teachers. Richmond, CA: McCutchen Publishing Corporation.

Chen, H. (2008). Learning in new times: Writing through the "eyes of genre". In P. Kell, W. Vialle, D. Konza, \& G. Vogl (Eds.), Learning and the learner: Exploring learning for new times. NSW: Wollongong: University of Wollongong.

Coe, R., M., \& Freedman, A. (1998). Genre theory: Australian and North American approaches In M. L. Kennedy (Ed.), Theorizing composition: A critical sourcebook of theory and scholarship in contemporary composition studies (pp. 136-147). Greenwood.

Culham, R. (2003). Theory \& practice: $6+1$ Traits of Writing. USA: Scholastic.

Cutler, L., \& Graham, S. (2008). Primary grade writing instruction: A national survey. Journal of educational Psychology, 100(4), 907-919.

Derewianka, B. (1990). Exploring how texts work. Sydney: Primary English Teaching Association

Derewianka, B. (1996). Exploring the writing of genres. Hertfordshire: United Kingdom: Reading Association.

Dixon, J. (1987). The question of genres. In I. Reid (Ed.), The place of genre in learning: Current debates (pp. 9-21). Deakin: Australia: Deakin University Press.

Emig, J. (1971). The composing processes of twelfth graders Champaign, IL: National Council of Teachers of English.

Flower, L., \& Hayes, J. R. (1981). A cognitive process theory of writing. College Composition and Communication, 32(4), 365-387.

Flowerdew, J. (2002). Genre in the classroom: A linguistic approach. In A. Johns (Ed.), Genre in the classroom: Multiple perspectives ( $\mathrm{pp}$. 91-102). Mahwah, New Jersey: Lawrence Erlbaum Associates.

Fowler, W. S. (1989). Progressive writing skills. Surry: Thomas Nelson and Sons Ltd.

Gilbert, J., \& Graham, S. (2010). Teaching writing to elementary students in grades 4-6: A national survey. The Elementary School Journal, 110(4), 494-518. 
Graves, D. H. (1983). Writing: Teachers and children at work. Exeter, NH: Heinemann Educational Books.

Halliday, M. A. K. (1978). Language as social semiotic. London: Edward Arnold.

Horowitz, D. (1986). Process, not product: Less than meets the eye. TESOL Quarterly, 20(1), 141144.

Hyland, K. (2007). Genre pedagogy: Language, literacy and L2 writing instruction. Journal of Second Language Writing, 16, 148-164.

Hyon, S. (1996). Genre in three traditions: Implications for ESL. TESOL Quarterly, 30, 693-722.

Krippendorff, K. (2012). Content analysis: An introduction to its methodology: Sage Publications.

Lee, D. P., Allen, R. V., \& Lamoreaux, L. A. (1963). Learning to read through experience. Englewood Cliffs, N.J: Prentice-Hall.

Martin, J. R. (1984). Reading, writing, spelling: Types of writing in infants and primary school. Paper presented at the Proceedings of the Fifth Macarthur Reading/Language Symposium, Sydney.

Martin, J. R. (1987). Factual writing: Exploring and challenging social reality. Geelong: Deaking University Press.

Martin, J. R. (1992). English text: System and structure. Philadelphia: John Benjamins Publishing Company.

Matsuda, P. K. (2003). Second language writing in the twentieth century: A situated historical perspective. In B. Kroll (Ed.), Exploring the dynamics of second language writing (pp. 1534). Cambridge: Cambridge University Press.

McCrimmon, J. (1994). Writing with a purpose. Boston: Houghton Mifflin Co.

McQuitty, V. (2014). Process-oriented writing instruction in elementary classrooms. Writing and Pedagogy, 6(3), 467-495. doi:10.1558/wap.v6i3.467

Miles, M. B., \& Huberman, A. M. (1994). Qualitative data analysis (2nd edition). Thousand Oaks, CA: Sage Publications.

Miller, C. (1984). Genre as social action. Quarterly Journal of Speech, 70(May), 151-167.

Ministry of Education. (2008). STELLAR: Strategies for English Language Learning \& Reading. Retrieved from http://www.stellarliteracy.sg/

Ministry of Education. (2010). English Language Syllabus 2010: Primary and Secondary (Express / Normal (Academic). Singapore: Curriculum Planning \& Development Division, Ministry of Education.

Murray, D. (1972). Teach Writing as a process not product. The Leaflet, 71(3), 11-14.
Nunan, D. (1991). Language teaching methodology: A textbook for teachers.: Prentice Hall.

Pennington, M. C. (2013). Evolutionary trends in writing pedagogy. Writing and Pedagogy, 4(1), $1-22$.

Pincas, A. (1982). Teaching English writing. London: Macmillan.

Raimes, A. (1991). Out of the woods: Emerging traditions in the teaching of writing. TESOL Quarterly, 25(3), 407-430.

Sandmel, K., \& Graham, S. (2011). Impact of the process writing approach on the quality of student writing: A meta-analysis. The Journal of Educational Research, 104(396-407).

Scott, V. M. (1996). Teaching Foreign language writing. In V. M. Scott (Ed.), Rethinking Foreign language writing. Boston, Mass., U.S.A: Heinle \& Heinle.

Serafini, F. (2012). Expanding the four resources model: Reading visual and multimodal texts. Pedagogies: An International Journal, 7(2), 150-164.

Spandel, V. (2005). Creating writers through 6-trait writing assessment and instruction. Boston: Allyn \& Bacon.

Spandel, V. (2008). Creating young writers: Using the six traits to enrich writing process in primary classrooms. Boston: Allyn and Bacon.

Stauffer, R. G. (1970). The language experience approach to the teaching of reading. New York: Harper \& Row.

Steele, V. (1992). Product and process writing: A comparison. British Council Teaching English, Writing, Creative writing for Language Practice. Retrieved from https://www.teachingenglish.org.uk/article/pro duct-process-writing-a-comparison

Swales, J. (1990). Genre analysis: English in academic and research settings. Cambridge: Cambridge University Press.

Tompkins, G. E. (2008). Teaching Writing: Balancing process and product (5th edition). Upper Saddle River, New Jersey: Pearson Education.

Tompkins, G. E. (2010). Literacy for the 21st century: A balanced approach (5th edition). Upper Saddle River, New Jersey: Pearson Education.

Weber, R. P. (1990). Basic content analysis. Newburry Park, CA: Sage Publications.

Wertsch, J. V. (1991). Voices of the mind: A sociocultural approach to mediated action. Cambridge, Massachusetts: Harvard University Press.

Wong, R. M. F., \& Hew, K. F. (2010). The Impact of blogging and scaffolding on primary school pupils' narrative writing: A case study. 